\title{
Exosome Complex Exonuclease RRP44
}

National Cancer Institute

\section{Source}

National Cancer Institute. Exosome Complex Exonuclease RRP44. NCI Thesaurus. Code C96360.

Exosome complex exonuclease RRP44 (958 aa, 109 kDa) is encoded by the human DIS3 gene. This protein is involved in the mediation of rRNA processing. 